<原 著 $>$

ヒトの硬変肝コラーゲンの生化学的性状 (II)

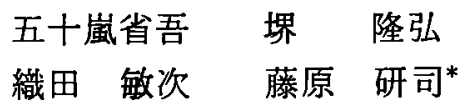

要 旨：ヒトの乙型硬変肝のコラーゲンを $1 \mathrm{M}$ 食塩（中性溶性 コラーゲン）, おょび $0.5 \mathrm{M}$ 酢酸 (酸溶性コラーダン) で抽出し，そのアミノ酸組成，糖含量および分子量を測定した。

1）ヒトの硬変肝から抽出されたコラーゲンもカルボキシメチルセルロースクロマトグラフィ 一により $\alpha_{1}, \alpha_{2}$ 打よび $\beta_{12}$ 鎖に分離出来る.

2） $\alpha_{1}, \alpha_{2}$ 鎖のアミノ酸組成は，ハイドロオキシプロリン，メチオニンが少なく，ハイドロオ キシリシン，ヒスチジンが多い， $\alpha_{2}$ 鎖により多く塩基性アミノ酸が含まれている.

3） $\alpha_{1}, \alpha_{2}, \beta_{12}$ 鎖ともに糖含量が著しく多く，糖を介する基質との結合が，ヒトの硬変肝の コラーゲンの抽出を困難にしているるのと考兄られる.

4） $\alpha_{1}, \alpha_{2}$ 鎖の分子量は $103,000,106,000$ と推定される.

索引用語: 肝硬変 コラーゲン フミノ酸糖

ヒト，の硬変肝に增生しているコラーゲンおよびェラス チンについて生化学的分析を行ない, シロネズミの実験 的肝硬変との間に若干の違いがあることについて，すで に報告してきだ、両者の主な相違点は，ヒトの硬変肝 のばあい, (1) コラーゲンの量が正常肝に比べて3〜 5 倍に增加しているにもかかからず，コラーゲンの可溶性 分画がシロネズミの実験的線維肝よりも著しく少ない， (2) エラスチンの占める割合が実験的線維肝より多く, 硬蛋白の約40\%を占める，(3) コラーダンのアミノ酸組 成はハイドロオキシプロリン（hypro）およびメチオニ ンの含量が皮唐ないし骨のコラーダンに比べて少なく， ハイドロオキシリシン hylys およびヒスチジンの含量が やや高い。しかし变性温度, 固有粘度には差を認めなか った.

さらに、ヒトの硬変肝組織から抽出されたコラーゲン について，カルボキシメチルセルロースのクロマトクラ フィーにより $\alpha$ 鎖および $\beta$ 鎖を分離し，それぞれのアミ 八酸組成，桾含量，分子量を検討したので報告する.

\section{方 法}

1） コラーゲンの抽出：まとして乙型硬変肝組織 200 〜 300日を粗に磨碎した後, ドライフイスを加えてミキ

* 東京大学 第 1 内科 <受付日 49年 2 月 8 日 >
サーで細かくしたものを，約 10倍量の $1 \mathrm{M}$ 食塩および $0.05 \mathrm{M}$ Tris を含む $\mathrm{pH} 7.2$ の溶液中でゆっくり擋拌し ながら一昼夜抽出（中性溶性コラーゲン），残渣をさらに 約10倍量の 0.5M酢酸で抽出した（酸溶性コラーダン）. 以下の実鏂には，主としてこの酸容性コラーゲンを用い た.

2）カルボキシィチルセルロース（CMC）クロマト グラフィー: CMC は Whatman CM 32を用い， $0.5 \mathrm{M}$ 塩酸.ついで $0.5 \mathrm{M} \mathrm{NaOH}$ で洗淮した後, $\mathrm{pH} 4.8$ の酢 酸ナトリウム溶液でさらに充分洗淮して用いた。カカ 厶は内径 $12 \mathrm{~mm}$, 長さ $100 \mathrm{~mm}$ の外套管付カラムを使用し， 溶出は $0.06 \mathrm{M}$ 眽酸ナトリウム溶液（イオン強度 $0.06, \mathrm{pH}$ 4.8）および0.06M酶酸ナトリウムに $1 \mathrm{M}$ 食塩を加えた pH 4.8 溶液（イオン强度0.16）をれぞれ $100 \mathrm{~m} l$ を用

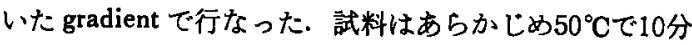
間加温して熱変性させたものを用い, UVICON 540紫外 吸収記䩮計（東洋機器）により，溶出された蛋白の 230 $\mathrm{m} \mu$ に批汁る吸収を連続的に記録した。溶出中カラムの 外套管は $45^{\circ} \mathrm{C} に$ 保ち，分離された $\alpha, \beta$ 鎖を含む分画は プールし，0.1N酢酸中で透析した後凍結乾燥した。

3）アミノ酸分析：凍結乾燥して得た前記の蛋白試料 $2 \sim 3 \mathrm{mg}$ を $6 \mathrm{~N}$ 塩酸に溶解, $100^{\circ} \mathrm{C} て ゙ 20$ 時間加水分解乙 たものについて，日本電子アミ，酸分析機 6 HA を用い 
て分析した. アミノ酸組成は，アミ，酸 1,000残基当り の各てミノ酸残基数を算定して表現した。

4）糖の分析：アミノ酸分析と同様に, 前記試料 2 $3 \mathrm{mg} 2 \mathrm{~N}$ 塩酸に溶解， $100^{\circ} \mathrm{C} て ゙ 20$ 時間水解した後グル コースおよびガラクトースはそれぞれ glucose oxidase 法 (Glucostat, Worthington), galactose oxidase 法 (Galactostat, Worthington)により,ヘキソサミンは ElsonMorgan 法 ${ }^{2)}$ で，ウロン酸は一定量の蛋白を $0.1 \mathrm{~N}$ 酢酸 に溶解した試料について, Bitter \& Muir の方法"によよ り測定した. 各桾の含量は $\alpha$ 鎖, $\beta$ 鎖のアミノ酸 1,000 残基に対する重量比で表現した。

5）分子量の測定 ${ }^{4)}$ : 径 $12 \mathrm{~mm}$, 長さ $700 \mathrm{~mm}$ のアガロー ス (Biogel A 1.5m) カラムを用い, 1 M塩化カルシウ ム, $0.05 \mathrm{M}$ Tris を含む $\mathrm{pH} 7.2$ の溶液で溶出した. 50 ${ }^{\circ} \mathrm{C}, 10$ 分間の温浴で熱変性させた試料に $0.1 \mu \mathrm{C}$ のトリ チウム水を加えて溶出, トリチウム水の溶出位置に対す る資料の相対的溶出位眉から分子量を算定した。

\section{成 績}

1） CMC クロマトグラフィー:Fig. 1に示すよらに 3つのピークが記録され, 皮唐や骨のュラーゲンの CMC

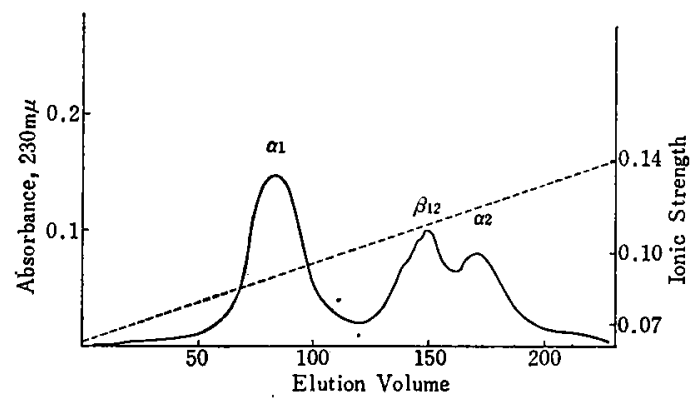

Fig. 1. CMC Chromatogram of Denatured Collagen extracted from Cirrhotic Human Liver

クロマトクラムと対比して, 溶出の早いるのから順に $\alpha_{1}, \beta_{2}$ および $\alpha_{2}$ 鎖之同定された. それぞれイオン強 度0.09，0.11，0.12の位固に対応する.

2）アミノ酸組成：Table 1 に酸溶性コラーゲン， $\alpha_{1}$ 鎖および $\alpha_{2}$ 鎖のアミノ酸組成を示したが, 数值はアミ 八酸 1,000 残基当りの各アミノ酸残基数である. ヒトの 硬変肝から抽出さ机た酸溶珄コラーゲンと同じく， $\alpha_{1}$, $\alpha_{2}$ 鎖ともに hypro は70，72とやや少なく，メチオニンむ 1.5および 1 残基と著しく少ない. 酸溶性コラーゲンに は微量のシスチンが検出されているが， $\alpha_{1} ， \alpha_{2}$ 鎖には痕 跡程度にしか認められなかった. ハイドロオキシリジン
Table 1. Amino acid composition of collagen extracted from cirrhotic human liver and its $\alpha$ components (residues/ 1,000 total residues)

\begin{tabular}{l|c|c|c}
\hline & $\begin{array}{c}\text { original } \\
\text { collagen }\end{array}$ & $\alpha_{1}$ & $\alpha_{2}$ \\
\hline 3-Hydroxyproline & - & - & - \\
4-Hydroxyproline & 64 & 70 & 72 \\
Aspartic acid & 63 & 52 & 66 \\
Threonine & 24 & 23 & 20 \\
Serine & 35 & 41 & 40 \\
Glutamic acid & 85 & 88 & 71 \\
Proline & 109 & 121 & 117 \\
Glycine & 305 & 311 & 317 \\
Alanine & 105 & 106 & 104 \\
Cystine & 0.5 & - & - \\
Valine & 36 & 24 & 21 \\
Methionine & 0.7 & 1.5 & 1.0 \\
Isoleucine & 18 & 14 & 11 \\
Leucine & 33 & 28 & 26 \\
Tyrosine & 4.9 & 4.0 & 5.6 \\
Phenylalanine & 15 & 10 & 11 \\
Hydroxylysine & 9.2 & 12 & 14 \\
Lysine & 33 & 33 & 31 \\
Histidine & 7.9 & 7.0 & 10 \\
Arginine & 51 & 55 & 62 \\
\hline & & &
\end{tabular}

特よびリジンは $\alpha_{1}, \alpha_{2}$ 鎖とむに皮庙，骨ュラーゲンの それよりもや多く，ヒスチジン残基数も多い。

$\alpha_{1}$ と $\alpha_{2}$ 鎖を比較すると $\alpha_{2}$ 鎖はアルギニン, ヒス チシン，ハイドロオキシリジンなとの塩基性アミノ酸を より多く含むことが確認された。

Table 2. Carbohydrates content of $\alpha_{1}, \alpha_{2}$ and $\beta_{12}$ chains of collagen extracted from cirrhotic human liver $(\mathrm{g} / 100 \mathrm{~g}$ of $\alpha$ and $\beta$ components)

\begin{tabular}{l|c|c|c|c}
\hline & Glucose & Galactose & Hexosamine & $\begin{array}{c}\text { Uronic } \\
\text { acid }\end{array}$ \\
\hline$\alpha_{1}$ & 4.3 & 3.3 & 0.9 & 1.1 \\
$\alpha_{2}$ & 5.1 & 4.7 & 1.0 & 2.4 \\
$\beta_{12}$ & 4.9 & 6.2 & 1.1 & 1.2 \\
\hline
\end{tabular}

3）糖含量： $\alpha_{1}$ 鎖および $\alpha_{2}$ 鎖を構成するアミノ酸 1,000残基に対するクルコース，ガラクトース，人キン サミン,およびゥロン酸の重量比 (百分率)を Table 2 に示した. $\alpha_{1}, \alpha_{2}, \beta_{12}$ 鎖はそれぞれ 4.3，5.1，4.9 
\%のグルコースを含んでおり，ガラクトースは 3.2,

4.7扰び 6.2\%を占めている.この值はネズミの皮府 コラーゲンの $\alpha$ 鎖が含むへキンースの約10倍量である. ヘキソサミン含量はそれぞれ約 1\%であった. またウ口 ン酸含量む $\alpha_{2}$ 鎖で $2.4 \%$ を示したが， $\alpha_{1}, \beta_{12}$ 鎖とも に約 $1 \%$ \%った.

な和表 2 の測定值は，4回の CMC クロマトグラフィ ーによって得た蛋白をブールした資料について得たるの である.

4）分子量：アガロースカラムを用いた分子篩クロマ トグラフィーにより得た $\alpha_{1}$ 鎖， $\alpha_{2}$ 鎖の分子量はそれ ぞれ 103,000および 106,000であった. 図2はヒト硬変 肝コラーゲンの $\alpha_{1}$ 鎖, およびネズミ皮庙コラーゲンの $\alpha_{1}$ 鎖のアガロースクロマトグラムを示したものである が，硬変肝の $\alpha_{1}$ 鎖はネズミ皮届のそれよりる分子量が やや大きいことがかかる (Fig. 2).

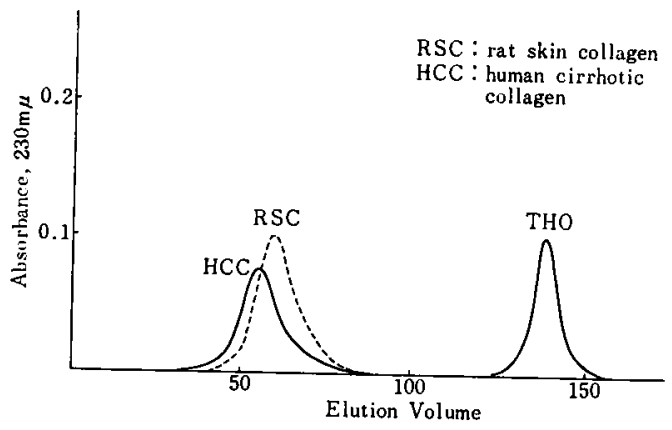

Fig. 2. Molecular Sieve Chromatogram of $\alpha_{1}$ Chains of collagen from cirrhotic human liver and rat skin

\section{考察}

硬変肝のコラーゲンは，ヒトのばあい，さきに述べた ように組織からの抽出が難かしい，それは中性溶性和よ び酸溶性コラーゲン分画の割合が，動物の実験的線維肝 よりもはるかに少ないことにより示されている. その理 由は, ヒトの硬変肝の成立に, 動物の実験的線維肝より もはるかに長い時間が要求されることにもよろらが，本 質的にはコラーゲン線維と周囲組織とのより密接な関係 を考虑する必要があろう，とトのばあいコラーゲンの糖 含量がとくに多く，シロネズミの皮应コラーゲンの糖含 量は $0.5 \%$ 前後とされているのに対し，われわれの測定 したヒト硬変肝の糖含量は 4 〜\%と異常に高い.

コラーゲンと糖の結合様式は2つ考えられている，第
1 はコラーゲンのハイドロオキシリジンにグルュース とガラクトースが O-glycosidic bond として結合した glucosyl-galactosyl-hydroxylysineであ ${ }^{5,6)}$, Kefalides $^{7)}$ Spiro $^{\text {(3) }}$ が腎系球体の基底膜コラーゲンの分析により，糖 含量の多いことに比例してハイドロオキシリシンの多い ことをあきらかにしている. われわれの硬変肝コラーゲ ンのばあいもハイドロオキシリシンの多いことから，增 加した糖質の一部は上記の disaccharide と考えられる. しかしハイドロオキシリジンの残基数よりも，グルコー ス，ガラクトース残基数が 2 倍以上多い. したがってこ れとは別の糖の結合様式も考劣られねばならない，

現在知られている第 2 の結合様式は，へキソサミン， ガラクトース，マンノース，ファースおよびシフル酸を 含む heteropolysaccharide である. disaccharide がンイ ドロオキシリシンに結合するのに対し， heteropolysaccharide はアスパラギンと結合すると想像されている9． ヒトの硬変肝コラーゲンにおいてこの第 2 の結合様式の 存在する可能性は否定できないが，ムュ多糖の構成要素 であるウロン酸とへキソサミンがほぼ等量に含まれてい る事実は，むしろュラーゲンとムコ多糖との何らかの形 での結合を示唆するすのといえる. 糖含量の多い杀球体 基底膜コラーゲンです，その他の組織由来のコラーゲン です, コラーゲンとムコ多楉が結合しているという生化 学的な報告はみられない，われわれの成績は，コラーゲ ンの抽出過程におけるムュ多榶の単なる混入とも考えら れるが， $\alpha$ 鎖， $\beta$ 鎖に分離精製された段階においてなお検 出されていることは，基質成分であるムコ多糖がコラー ゲンと結合しており，精製の操作を維てむなおとの一部 分が残存する可能性を示している. Laros and Cooper ${ }^{12)}$ が，軟骨のコラーゲンにムコ多糖と思われる物質が規則 正しく配列結合していることを電影的に証明しており， 今後解明されるべき問題であろう.

多量の糖を含むニワトリの軟骨コラーゲンが通常の方 法では抽出が極めて困難である ${ }^{10,11}$ のと同様に，ヒト硬 変肝コラーダンに含まれる榶が周囲組織と密接に結合す るために抽出を困難にしていると考えたい。

ヒトの硬変肝コラーゲンの $\alpha$ 鎖の分子量がネズミの皮 唐のそれよりる幾分大きいのは，糖含量の多いことから 説明されよう。

なおアミノ酸分析でメチオニンが著しく少ないのは特 異的であり，水解の過程での変化，たとえは酸化されて メキオニンスルホン酸に変化したとる考觉られるが，ア ミノ酸のクロマトグラムではメチオニンスルホン酸はは 
とんど認められていない，牛の心弁膜のコラーゲンの分 析 ${ }^{13)} て ゙ も$ 同様の報告があるが，その解明は今後に残され た問題である.

$$
\text { まとめ }
$$

1）ヒトの硬变肝から抽出されたコラーダンむ CMC クロマトグラフィーKより $\alpha_{1}, \alpha_{2}, \beta_{12}$ 鎖に分離でき る.

2） $\alpha_{1}, \alpha_{2}$ 鎖の丁ミ八酸組成は hypro がやや少な く、メチオニンが著しく少ない，Hylys，ヒスチシンが や巾多い， $\alpha_{2}$ 鎖に，より多く塩基性アミノ酸が含まれ ている.

3） $\alpha_{1}, \alpha_{2}, \beta_{12}$ 鎖ともに榶含量が著しく多く，煻を 介する基質との結合がュラーゲンの抽出を困難にしてい るすのと考点られる.

4） $\alpha_{1}, \alpha_{2}$ 鎖の分子量は 103,000，106,000 と推定 される.

\section{文 献}

1）五十嵐省吾, 藤原研司他：ヒト硬変肝コラーゲ ン・エラスチンの生化学的研究一実験的線維肝 との比較. 肝缄, $13: 691,1972$.

2) Elson, L.A. \& Morgan, W.T.J.: A colorimetric, method for the determination of glucosamine and chondrosamine. Biochem. J., 27: 1824, 1933.

3) Bitter, T. \& Muir, H.M.: A modified uronic acid carbazol reaction. Analyt. Biochem., 4: 330, 1962.

4) Piez, K.A.: Molecular weight determination of random coil polypeptides from collagen by molecular sieve chromatography. Analyt. Biochem., 26: 305, 1968. 


\title{
Biochemical Analysis of The Collagen from Cirrhotic Human Liver
}

\author{
IgARAshi Shogo, Sakai Takahiro, Oda Toshitsugu and \\ Fujiwara Kenji
}

The collagen was extracted from B type cirrhotic human liver with $1 \mathrm{M} \mathrm{NaCl}$ and $0.5 \mathrm{M}$ acetic acid, and its chemical composition and molecular weights of $\alpha$-components were analysed.

1) Collagen from cirrhotic human liver was separated into $\alpha_{1}, \alpha_{1}$ and $\beta_{12}$ chains.

2) Amino acid analysis of original collagen and its $\alpha$-components showed lower content of hydroxyproline and methionine, and higher amount of hydroxylysine and histidine. Content of basic amino acids in $\alpha_{2}$ chain was higher than that in $\alpha_{1}$.

3) The sugar components which occupyed more than 10\%, were identified as glucose, galactose, hexosamine and uronic acid. Higher content of carbohydrates indicate presence of interaction between collagen and structural macromolecules such as acid mucopolysaccharides.

4) Molecular weights of $\alpha_{1}$ and $\alpha_{2}$ chains determined by molecular sieve chromatography were 103,000 and 106,000 respectively.

First Department of Internal Medicine, Faculty of Medicine, University of Tokyo (Tokyo) 